\title{
A2A Relationships in Service Contexts
}

\author{
Luca Carrubbo, Andrea Moretta Tartaglione \\ Cassino University, Cassino, Italy \\ Primiano Di Nauta \\ Foggia University, Foggia, Italy
}

\begin{abstract}
This work aims at developing the actor-to-actor (A2A) relationship concept in service contexts enhancing the contribution of the systems theories. The most recent progresses related to the research on the service, as a matter of
\end{abstract} fact, highlight how the nowadays co-creation processes are key elements in each service context. Both the Service Science (SS) and the Service Dominant (S-D) logic analyse the importance of the role played by the numerousness of actors involved in the service exchange because of the resources held (and released) and the contribution they can offer. System theories, and in particular the Viable System Approach, offer the possibility of an holistic perspective able to re-interpret the same characterizing mechanisms of the value co-creation. In the following parts of the work it will presented a conceptual analysis based on the contribution of the VSA, the SS and the S-D logic, whose scientific proposals will be developed and critically analysed in order to verify the proposition coherence in terms of A2A relationships within the value co-creation process. The relational perspective of the Service Eco-systems shows a view open to network in relation to economic and social actors, where each organization can be considered as an actor because it is actively committed in the value co-creation development, going beyond the difference between the user, the producer, or the exchange facilitator. Therefore, the contribution proposes some progresses compared with the business to business (B2B) approach and literature, through the introduction of the new A2A interaction concept within the service context for the indistinct role that the actors play in the value co-creation process. In this perspective, the contribution introduces the research line focused on the service, giving attention, afterwards, to the service system context, in order to analyse the features of these systems with the specific goal of identifying its peculiarity. The contribution proceed with the presentation of the systems thinking, and in particular the VSA contribution, directed toward the description of the gaps that the authors identify in the present research attempting to offer some orientations for the comprehension and the improvement of the service systems and of their planning and management implications. The contribution finally proposes an integrated interpretation of the several emerging paradigms (VSA, SS and S-D logic) seeking an in-depth-analysis of the A2A relationships in the service contexts.

Keywords: A2A relationships, Viable System Approach (VSA), service context, Service Dominant Logic (S-D logic), Service Science (SS), value co-creation

Luca Carrubbo, Ph.D. in Business Management, Department of Economics and Law, Cassino University.

Andrea Moretta Tartaglione, Assistant Professor in Business Management, Department of Economics and Law, Cassino University.

Primiano Di Nauta, Assistant Professor in Business Management, Department of Economics, Foggia University.

Correspondence concerning this article should be addressed to Luca Carrubbo, Via Sant'Angelo snc, Località Folcara, 03043, Cassino (FR), Italy. E-mail: l.carrubbo@unicas.it. 


\section{Introduction}

Today, the business world is more and more interested and oriented toward the research on complexity as it is evident that, to face new situations and to survive the new challenges of the modern dynamic context, the traditional interpretational schemes, which are often based on predefined and standardized solutions, shows their inadequacy (Aguiari, 2002; Barile, 2009).

Because of the growing dynamism of the contexts and the consequent growth of variety, the management of the organizations leans to the adoption and the "refuge" in structured or semi-structured models in order to ease the decision-making process. However, it has progressively glided toward the consideration of situations that are typically connected to the government and, for this reason, fundamental for the survival of an organization, such as problem-solving situations, even if they are connected in a much more cogent way to the decision-making reign. With reference to this direction, the researchers have observed this evolution, recognizing the importance of the necessity to widen the research horizons when government themes are approached. As a matter of fact, if on one side the organizations have become aware of a lot more stable and foreseeable ambient, on the other side we have watched a rush, often not justified, toward approaches which are rational to the decision-making process.

In the world of organizations, the decision makers are often burden with an excessive responsibility of dynamics management within the decision-making contest where the problem-solving is not fundamental as the action of making choice, often without any supporting information (Barile, 2009). In such a scene, the occurrences have often proved the inadequacy and the embarrassment of some solutions which have been identified. As a consequence, these solutions have often been identified as "complex" solutions. However, is it correct to consider a phenomenon complex in itself? How can we explain why some people can perceive a different complexity related to the same phenomenon? Which are the features that allow attributing the adjective "complex" to a certain phenomenon?

These questions have pointed out some recent reflexions in the field of the systems thinking applied to social and economic contexts, starting from the assumption of the organization which are considered as viable systems and proposing a methodological system approach as a perspective through which new interpretative schemes for the management of complex contexts can be extrapolated. It is the research perspective well-known as Viable System Approach (VSA) (Golinelli, 2000, 2005, 2008, 2010, 2011; Barile, 2000, 2008, 2009). The company staff or managers, find themselves at dealing with conditions of a growing complexity within the decision-making processes of the organizations government (Simon, 1969, 1945, 1997; Saviano \& Di Nauta, 2011; Di Nauta, 2010; Saviano \& Berardi, 2009; Barile \& Saviano, 2010). However, in these situations the decision-making models performance (synthetic schemes) are essentially adequate to face the complication and not the complexity.

Usually the term "complex" is reserved to objects, or well-defined situations, while it should indicate, in a more correct way, the context where the object or the situation is perceived. The circumstance that the perceived complexity can be attributed to a material object, such as Rubik's cube, can be considered as simplistic. As a matter of fact, Rubik's cube can be considered complex in itself, but complex can be defined the processes for its solution. Therefore, the cube is complicate in the sense that, despite its difficulty, it can be solved (Barile, 2009). From a theoretic point of view, there are several potential connections between the most important approaches to 
the research on the service-Service Science (SS), Many-to-Many approach and the system theories. This analyses of relationship aims at governing and supporting the decision-making processes, with the goal of synthesizing and providing a shared and a new perspective for the government of the business dynamics within practical operations. In particular, the nature which is intrinsically based on S-D logic (Lusch, Vargo, \& O’ Brien, 2007; Vargo \& Lusch, 2008a; Vargo, Lusch, \& Malter, 2006) and SS relationships (Spohrer, Maglio, Bailey, \& Gruhl, 2007; Spohrer, Anderson, Pass, \& Ager, 2008; Spohrer, Vargo, Maglio, \& Caswell, 2008; Maglio, Srinivasan, Kreulen, \& Spohrer, 2006; Maglio \& Spohrer, 2008a, 2008b, Maglio, Kieliszewski, \& Sporher, 2010; Katzan, 2008) provide a fertile ground of comparison, while the VSA can provide some interesting (and potentially useful) contributions in the interpretation process and in the relationships government.

The interpretation of the complexity made from the viable systems point of view underlines the relevance of the aspects which emerge in the light of the perspective change that, in turn, intervenes by adopting the lens of the systems approach, with an attempt of providing a connection between the service paradigm and the many-to-many logic (Gummesson, 2004, 2006, 2008a, 2009). Therefore, the conceptual analysis on the recent progresses in the study of the relationships have a government aim, in order to propose a methodology where the above-mentioned disciplines can find comfort and converge. In this direction, it can be found some important aspects belonging to the emerging theories on the service and systems, a projection on the nature and the principles which are the base of the VSA, by focusing on the relationships of government and on the decision-making processes.

\section{Context of the Service Research}

The growing importance of the services compared to goods, seen in a traditional way, and their permanent role in almost all the commercial transactions of the modern global economy, encourages scholars, actors, and business experts, to engage in the research of models, paradigms, and theoretic constructs, giving a contribution to a revealing change in perspective within the international scientific literature. As a matter of fact, there are many attempts of a goods-services relationship inversion (especially present in the conventional paradigms), in order to analyse and examine in depth the considerations related to their exchange and use, to re-examine the concepts of value and its creation and to interpret again the meaning of interaction, relation, and loyalty.

The study of the international literature on the services themes, allows us to learn that, nowadays, the intersection between demand and supply occurs at different levels and with several modalities, especially according to the features of the product that is demanded and supplied. This intersection depends on the capability of mobility and accessibility that the resources have (both connected to the relocation), and it depends on the information and communication capability (connected to the knowledge and that nowadays are favoured by the coming of the Internet); on the fruition modality (connected to the quality and innovation of the allocation systems) (Mele, 2009; Carrubbo \& Sarno, 2010); on the efficiency granted in terms of procedure, reliability, image, competence, adaptability. In this sense, taking back Gronroos'(1990) and Gummesson's (1987) definitions, it is possible to state that a service is a process which consists of a series of activities, of a more or less tangible nature, that normally, but not necessary, take place in the interaction between the customer and the employee and/or between physical resources or products and/or systems belonging to the service provider, that are provided as solutions to the customer's problems. 
Nowadays we can find a growing presence of services in all the productions (far-back Service Economy is discussed-Levitt, 1981), and the traditional dichotomy between goods and services gradually leans to lose its tone and meaning (Kotler, 1977; Normann, 1991; Rispoli \& Tamma, 1992; Cercola, 1996). Companies, including the industrial ones, more and more take into consideration the possibility of enriching their own supply through the addition of services, looking for opportunities of interaction, respect and loyalty, traditionally not always implied in the physical product in itself, in order to revise the business role and its relationship with the market (Grönroos, 2006).

The classic logic, based on the clear separation between consumers and producers and on the simple distinction between goods and services, is now defined "yesterday logic" (Drucker, 1993), as it is considered totally contrasting with the most recent interpretations based on network relationships, continuous interactions, value co-creation (Ravald \& Grönroos, 1996; Grönroos, 2008), all elements which are considered more close to the modern economy (Rust, 2004). Although this idea of transversal and omnipresent service is not completely new (Borgonovi, 1996; Sicca, 1996; Rullani, 1997; Baccarani, 1997), it appears definitely in line with the changes of the global markets that are more and more interconnected, dynamic and characterized by a strong turbulence.

Nowadays, the activities related to the service are not looked at as something secondary, complementary, or supporting, but they appear more and more frequently as a core elements (at least from a conceptual point of view) of many organizations; often a service centre does not need to be compared with something specific to be legitimated or set.

What in a previous time was commonly defined "third sector" but today which represents something completely renewed, revealing, incisive, and crucial. Services let the world economy move and, in particular, we refer to the economy of the most developed countries. Nowadays, we live in a services age. Several factors, policies, actions, business strategies, individual behaviour, intention between people having organizational perspectives, and supply chains, are connected with service logics. With the growing importance of the services in all the commercial activities and considering the possible change of the dominant logics, that are much more oriented toward the service of yore, nowadays companies seem to orient their own core toward the service, paying particular attention, in all the company function, to the culture of service and basing their competiveness also on the quality of the service performance and its innovation.

We can point out a common effort with the aim of sensitizing the international public opinion of the utility, the importance, the role and the application of "services" in all the productive sectors and their revealing influence in the value creation process (Carrubbo, 2009; Polese, Sarno, \& Carrubbo, 2009; Carrubbo \& Ciasullo, 2011). Some of these new interpretative lines, nowadays considered as dominant, are the outcome of a long historical process of interpretation which involves economists, sociologists, engineers and mathematicians who have focused on a new concept of service. From this perspective, the Service Dominant Logic (S-D logic) (Vargo \& Lusch, 2004; 2006; 2008a) and the Service Science (SS) (Maglio \& Spohrer, 2008a, 2008b) is born as the main expression of an out-and-out cultural movement-the service research.

In literature, the servicescape concept is defined as "the environment which surrounds the service" (Bitner \& Brown, 2006), considering not only the referring social ambient, but also the role of each entity (actor) which carries out activities and covers a role identifiable with the concept and, especially, with the service logic. All the 
company activities can be connected to the service: from ICT, to marketing and management policies, to R\&D services, to legal services, to financial services, to recruiting, to the accounting and so on. All these elements are referable each other, considering the direct and traditional relationships and also the indirect interactions, within an interpretative over-system, in a continuous updating, which can be considered as a sort of service age (that is the age of the service).

In SS perspective, the service is considered as a system made of parts interacting and interdependent between people, technologies and commercial activities (Sporher er al., 2007), always seeking the possibility of relating itself (Sampson \& Froehle, 2006), in order to use the distinctive capabilities that they own to get a competitive and lasting advantage (Chesbrough, 2005).

According to the S-D logic, the service is seen has "the application of competences, through actions, processes and performance, with the benefit of another entity", and it represents "the increase of value for physical goods" (Vargo \& Lusch, 2006, 2008b). In general "services are intangible activities customized according to the single request of well-known customers" (Pine \& Gilmore, 2000), the relative customizations take to co-production relationships, considering the customers as the real participant of the process and the real key component able to distinguish a specific model of service system from the traditional economic one.

Services can also be defined as a series of activities in which the resources that have a sort of interaction with the customer or the final user (employees, material resources, goods, person who offers a service) are used in order to find out some solutions (Grönroos, 2008), according to this perspective, the service can be identified with both the supplier and the customer operations, and their relationship can be considered as a system of parts that interact to carry out the service. So services are bargaining chips and they are used as particular point of view in the value creation process, especially in qualitative terms.

The service can be considered as an act or a performance (Berry, 1980; Zeithaml \& Bitner, 1996), an activity or a series of activities provided as solution to customers' problems (Grönroos, 1990), an economic process that does not produce a physical product nor has born from a construction. It is immaterial and perishable, created and contemporaneously used, an immaterial experience for a co-producer customer, a change of condition or an economic entity state caused by a third party, characterised in its nature (kind of action and receiver) by the relationship with the customer (kind of delivery and relationship), by decisions (customization and judgement), by delivery modalities (customers localization and physical or virtual nature of space) (Lovelock, 1983), a kind of interaction between different entities turned to particular outcomes, especially the result of value co-creation (win-win logic), "usually, a service element is considered as a process — or a diversified group of activities - in principle applicable to companies, instructions, public administration” (Katzan, 2008).

So the service represents a "sort of interaction between the entities of a reticular system aimed at improving the value of the co-creation process outcomes, in compliance with a win-win logic, within a group of processes which are closely related to each other" (Polese, Russo, \& Carrubbo, 2009; Polese, Carrubbo, \& Russo, 2010).

From this point of view, we speak in general of a new service mind-set (service culture), which is an orientation toward the innovation of the interaction customer-provider (service systems and value proposals), combined with the abilities to create relationships (Polese \& Carrubbo, 2008; Carrubbo \& Sarno, 2010). The consequent servicisation can be seen as a process that starts from the product producer and leads to a business model oriented toward the services. 
Once defined and legitimated the service role and its already famed significance, the conceptualization of the space where it is conceived, realized, supplied, and used, has been subjected, in the course of time, to continuous evolutions that have led to many interpretations of the so called service systems. First of all, a service system appears connected to supplier/customer interactions and, therefore, it is seen as an open system (Golinelli, 2011), which is able to enhance its own equilibrium status through the resources acquisition, sharing and supply. According to IBM researcher, the most little service system is the single person, while the global economy represents the biggest one. The service systems, according to the first real definition of the SS, represent configurations of people, technology, value proposition and shared information able to co-create value, such as languages, laws, measurements and methods (Spohrer et al., 2007). Therefore, each service system represent, at the same time, a service supplier and user, that is structured, according to its necessity, as a value chain, a value network, a value system (Vargo, Maglio, \& Akaka, 2008). The service system can be a mere software application, a business unit within a certain organization, can derive from a work team, from a company department; it can be a company, an institution, a governmental agency, a city, a nation, it can be a composition of many connected service systems in or out of the organization (Qiu, Fang, Shen, \& Yu, 2007). So a service system can act as a resources supplement, that can be interpreted in terms of group of elements belonging to a unique work system (Spohrer et al., 2008b), able to favour the competences specialization, whether operative and operating, such as knowledge, capability, know-how, people, producers, materials, finances (Vargo \& Lusch, 2006). The service systems are defined as system of work where the services suppliers and consumers share knowledge and information within a dynamic, specific and reticular supply chain of the value (Alter, 2008). The service systems can interact in a formal or informal way, informal interaction acquire significance through implicit or explicit compliance and by respecting the social rules for the public governance, on the contrary, formal interactions are connected to official provisions which fix the rules for agreements, licences, rights and that are safeguarded and granted by the presence of a recognized authority (Spohrer et al., 2008). Suppliers and customers are complex service systems that lead actions within a certain market in order to obtain expected results such as solution and experiences (Mele \& Polese, 2011).

So service systems can favour connections and interactions among the several actors involved into an exchange process by following different communicative channels between companies, users and various stakeholders (Gummesson \& Polese, 2009).

The SS recent evolution has proposed the development of a study focused on the modern service systems, intelligent, smart-type, encouraged in particular by the progress registered at an international level in the ICT (Spohrer et al., 2008). The fundamental idea is based on the necessity to consider more the organizations that are mainly able to face the changeable context conditions in a more reactive, adaptive, proactive and dynamic way (Barile \& Polese, 2010b; Carrubbo, 2010).

Gradually the new technologies shall be more and more able to re-configure themselves and the system, including the companies, to which they have been destined, in particular, companies will have to be more and more able to reformulate and reorganize the group of their own assets in order to maintain a stable and sustainable equilibrium in the course of time. In the future, as a matter of fact, all will be correlated, interconnected, and for this reason since now the attention toward the acknowledgement processes has grown as for the innovative processes, the technical progress, the reticular logics, the standards of quality measurement. In a smarter world, 
only systems (whether productive, conceptual, related to IT etc.) that presents particular smart-type characters and that are able to manage their selves in the best way within all the sectors of application, as in the water management, as in the electric energy distribution, in the public transport, in the professional education and in the public health, find a right and an adequate space (Napoletano \& Carrubbo, 2010; De Santo, Pietrosanto, Napoletano, \& Carrubbo, 2011).

\section{Contribution of the Systems Thinking for the Service Comprehension}

The VSA represents, nowadays, a scientific proposal that can be described as the key methodology for the analysis of complex phenomena (Golinelli, 2000; Barile, 2008; Barile, Pels, Polese, \& Saviano, 2012). It is focused on original representations of behavioural entrepreneurial approaches and on the related interactions between the company, here meant as system, and its own referring context (theoretical approach). The VSA is inevitably connected with the network studies, and it is based on the systems general theory, the social sciences and on many others disciplines concerning cognitive spheres completely different from economy (the main actual application), such as natural and IT sciences.

The VSA can be used for the formulation of definitions and postulates which determine the nowadays company behaviour that is basically aimed at achieving a unique final common goal: the survival. This important interpretation allows the analysis, the interpretation and the management of determinant factors from a particular point of view, which differs from those ones that have been consolidated in economy, the consideration of the entity object of the study (a company, an individual or any other existing organism) from a system point of view, allows to find out the critical elements (also the environmental ones) with whom it has to deal in order to succeed in facing the numerous external and internal changes that, especially in long terms, can influence its actions. From this point of view any organization action is contextualised in a dense group of relationships which are branched off within the structure of a company-system (so considering that also its sub-components—sub-systems), stretching to its external side and relating itself to all the possible system over-structure (significant or not-over-systems) that, in a direct or indirect way, can influence the action, the strategies and the outcomes of an organization (Saviano, 1999; Barile, Franco, Nota, \& Saviano, 2012b).

The VSA, which is developed from an interdisciplinary interaction between the holistic theories and the reductionist ones (von Bertalanffy, 1956), is based, according to the system thinking and to the related implication in terms of relationships, on the system concept and it is oriented toward the interpretation of its construction and organization, of its behaviour and evolution, of its relationships and interactions. The system we study, therefore, can be meant as a micro-ambient made of several associated parts (Parsons, 1965), made of a series of elements which are interconnected in order to achieve a common goal.

So the VSA encourages the analysis of the relationships between the inner elements that constitute a company besides the relationships between companies and other system entities inserted within the same context. From this point of view a system, to be so defined, it must be characterized by: (1) many tangible and intangible sub-components; (2) interdependence and communication between these sub-components; and (3) necessity to activate the relationships in order to achieve the system finality (Barile, 2000; Barile \& Saviano, 2008). Each system, to be so defined, must be able to manage its relationships with the outside, respecting the rules, the roles, and the shared responsibilities, in an attempt to succeed in satisfying the common interests of the system entities 
involved in its process of value creation (Golinelli, 2000; Barile, Montella, \& Saviano, 2011). Considering that two identical system do not exist, each one stands out for the characteristic "structural" elements from which it derives and also for (in case of the same structure) the presence of improvement in the knowledge (technicalities), in the operative experiences (practicalities), in the competences (skills and abilities) that can improve in the iterations and in the course of time, it is fundamental to understand levers which can be considered in order to favour the development and the implementation of a synergy. The necessary process for a continuous learning aimed at favouring the adaptability and the sustainable development, encourages continuous interactive connections with elements or subject that can be considered internal (intra-system relationships) and especially with third entities which are as much interested in the action object of this study (inter-system relationships) and with the above descripted influent/significant entities (supra-system relationships), through appropriate knowledge-type technics and procedures, aimed at encouraging co-design, co-production, co-marketing, co-creation solutions that are all directed toward a scope that is unique for any entity-the survival.

In reference to the distinction that exists between the static structure, which is the basis of any organization, and the dynamic system that originates from it after the activation of the relationships existing between the component elements, according to the VSA the consonance represents the basic compatibility between two system entities, the potential harmony of a relationship that can be related exactly to the structure (Golinelli, 2000; Barile, 2008; Barile et al., 2012a); on the contrary, the resonance concerns the effective harmonic and dynamic interaction between two systems, as consonance ideal evolution (its acceleration, its second derivative) (Barile, 2008), fundamental for a synergic one-to-one union, aimed at favouring the common satisfaction of a collective behave.

According to the VSA, the relational development between system entities is referred to the consonant and resonant relationships which can be found in the long term. Nowadays the competitive behaviour is strictly connected to the ability of identifying and managing functions, communicational channels, informative streams, rationalizing and harmonizing a sustainable development, adjusted to the iridescent external ambient (Christopher, 2007; Barile \& Di Nauta, 2011; Barile \& Polese, 2011; Barile \& Saviano, 2011a, 2011b).

The modern decision-making processes follow interpretative logics aimed at reducing the difficulties implied in the organizational processes, and at favouring new communicative architectures which improve the system performances (Demirkan \& Gaul, 2006). The informative variety and the variability of the possible reticular interconnections within the service systems, promote new forms of co-cooperation which can be interpreted as relational interactions among the actors of the system that is cognitively adjusted. At the same time, the possibility to explore the creation processes in a network context, as the structure of a dynamic system and the users' expectations, identify the "complexity of the ecosystem” (Basole \& Rouse, 2008) in which all is collected, identified and operated; this complexity does not depend just on the number of the actors, but also on the conditioned probability that these actors are involved in the service supply process (Barile \& Polese, 2009).

In the VSA, the word "viable" refers just to the capability of building the adequate relationships with the surrounding ambient and of running all the actions which are necessary for the organization survival, especially in the long period (Golinelli, 2000; Barile, 2008; Barile et al., 2012a). The "viable" concept, in this sense, is different form the "living" or "vital" one, as it is not referred to something that in a specific moment can live, but to something that is autonomously able to grow its own survival possibilities. A system is made viable from the 
behaviour adopted (also in the value creation point of view), more strategic, more reactive, more adaptive, more intelligent. The qualification and the valorisation of the relationships, the new planning of the organizational configurations, the complexity management, the common participation to the value creation process, are all elements that identify a successful system.

So, in this cognitive system board, it is possible to understand how the VSA nowadays represents a useful methodological framework, which is able to analyse the systems development, by introducing concepts such as the adaptation, the transformation, the reorganization to describe the changes to whom an entity can refer in order to comply to the external changes that punctually occur in the course of time (Golinelli, 2000; Barile \& Polese, 2010a). This allows understanding in how many modalities the organization can be reorganized (in a more lightweight and radical way) in order to face the changing reality in which nowadays is operating to be really viable, moreover, considering the service oriented perspective of the modern actions, a so structured service system, that exploits reticular synergies and co-creation advantages, can be considered smart (Maglio et al., 2010; Barile \& Polese, 2010b; Barile \& Polese, 2011) to all intends and purposes, and able to really survive within a so complex ecosystem (Lusch, 2011). When some ambient contingences occur, organizations are able to survive within a particular context only by improving their capability of evolving and making their operation adapted to the external changes. As a matter of fact, the opening of the studied systems (service system for SS and S-D Logic, value network for the network theories, viable systems for the VSA), imply an adaptation that is, from an homeostatic point of view, dynamic to external changes, and the survival of the same systems is directly connected to the capability of seeking and promoting dynamics and satisfactory evolutions.

Ultimately, nowadays service systems (smart and for this reason viable) are not defined only through simple relationships between resources: some resources must be operative, interacting, and they must propose, arrange, and evaluate value co-creation processes that are often, but not always, linearly defined.

The supply chain is re-conceptualized as a service system network, and for this reason it shows an a priori definable configuration, but able to be iridescent, to adapt and evolve in respect to the context condition.

The knowledge contribution, the appliance of competences, the configuration and re-configuration capability, the willingness to interweave long terms relationships with subject considered strategic, are elements of a system way to be adaptive.

\section{Interpretation and Governance of the Relationships According to the Systems Thinking}

All the relationships exist within the networks. Capra (1997) pointed out that the life consists of a relationships network through which the actors interact. The network theory, therefore, has much to offer to the customer relationships management (CRM) in the world of the entrepreneurial organizations.

In step with the relational approach to the described business, the network theory considers each entity as a dynamic resource that is active in the reticule of interaction which concerns the many-to-many relationships (Prahalad \& Ramanswamy, 2000; Loveolock \& Gummesson, 2004; Achrol \& Kotler, 2006; Gummesson, 1993, 2008a). According to this perspective, the network relationships influence and determine the organizations behaviour, their strategies and policies, typically oriented toward the mutual satisfaction which can be obtained thanks to the relationships between component and/or organizations (Lusch, Vargo, \& O’Brien, 2007).

Still referring to the network theory, the organizations are not autonomous entities. They depend on 
individuals and relationships networks that exist among them (Vicari, 1991).

As individuals interact in step with the behavioural cultural frames, in the same way the organizations adopt some social path and cultural attitudes in the interaction with other entities. Successful organizations, and by consequence the network to which they belong, are for example oriented toward the expression and the development of a win-win relational culture (Spohrer et al., 2010) rather than assume short terms opportunistic behaviours. So they are oriented toward co-creation processes through the instauration of long period relationships and toward the value sharing, that requires a continuous improvement in the interaction between the network entities (actors), in the research of the resources allocation optimization process and in the sharing of the advantages deriving from the collaboration and the cooperative strategies (Castells, 1996; Gulati, 1998; Capra, 2002; Mele, Spena, \& Colurcio, 2010).

This kind of relationship is typically characterized by the exchange of information concerning the referring context for the improvement of the mutual confidence (Richardson, 1972; Hakansson \& Ostberg, 1975).

In literature, we find several terms used for the description of these voluntary connection between organizational entities, as for instance, “eterarchy” (Hedlund, 1986) and "polycentric structure” (Forsgren, Holm, \& Jackson, 1991). However, the term which seems to predominate in the description of emerging economic entities is "network" (Bartlet \& Ghoshal, 1990). Therefore, the networks theory is oriented toward the analysis of the resources sharing and network goal achieving phenomena through several organizational constructs that can be used to analyse and explain the numerous contributions to the value creation in the followed systems (Polese, 2004; Polese, 2009a, 2009b; Polese \& Minguzzi, 2009).

In opposition to the traditional conceptualization of the value chain, the networks theory deals with the distinctive resource notion (attributed to the capabilities of a single entity), to embrace the idea that each entity benefits of the capability to re-set up its own service system in collaboration with other entities belonging to the network, in order to realize a valuable network for the service (Allee, 2000) in which the entities are incorporated (Granovetter, 1985).

Beyond the several service suppliers of a valuable network, another key element in the network theory is represented by the enablers. They promote the interactive exchange processes and the development of relationships within the network through direct and indirect connections with other service systems which are external and independent (Polese et al., 2009; Polese \& Di Nauta, 2012).

In short, the network theory allows to interpret the service systems as network where the functional interdependences among the actors exist, in order to face the growing level of ambient complexity (Richardson, 1972; Hakansson \& Snehota, 1995). In this perspective, the transactional models and the sequential linear dies, denounce their obsolescence. On the other side, the network interactions can be interpreted as drivers of the value, as the entities (actor) which take part in this process, develop a collaborative process of value creation, creating in this way a competitive advantage just thanks to the relationships.

Although the S-D logic, the SS and the VSA shared many common elements, with a rather strong correlation, in any case they represent different conceptual levels. According to the authors that at first have proposed and founded the basis for the modern service research, the main difference between the S-D logic and the SS lies essentially in the analysis perspective. The former can be interpreted as a "scalable" solution for the comprehension of the exchange, due to its proposal of a perspective change (in respect to the Goods-Dominant 
logic), considering the dominant service logic for each market interaction, included those one where the products exchange occurs. This perspective of the service defined above leads to a new view of the business strategies that pays much more attention to sustainability of the solutions and to the relationships with the final users in order to be able of ensuring an adequate service. The latter, otherwise, seems to be much more connected to the application world, also thanks to the origins from which it takes its shape and that are strongly based on concrete problem and on the possible management solutions.

In the attempts of giving value to the contribution of the several disciplines, the SS tries to highlight a shared paradigm for the process interpretation, and includes the service logic, through which it seems possible to connect the different activities with the aim of improving the outcome of each system (actors). Moreover, the SS finality is just that of highlighting the main features of the service systems.

\section{The Understating of A2A Relationship Within a New Relational Path: The VSA Contribution}

Given that the S-D logic, the SS and the VSA are strongly based on the relationships, it would be very useful to be able to synthetize the several approaches arriving to solutions for the relationships interpretation with the goal of governing them. One of the most interesting contributions that the VSA can offer to the relationships governance theme is just the understanding of the systems evolution. Developing system owns several abilities and capabilities that have gradually grown from the participation to a higher level system or network. Systems are considered complex, and by consequence characterized by feature fundamental for the competitiveness support, only when they have developed a positive efficacy interactions (according to consonance and resonance logic). Now, as the competitiveness in the VSA is strongly related to the viability one (that in turn is connected to the concept of consonant and resonant interaction among systems), each entity of a given system share its own resources in favour of another system within a relational win-win logic. The consonance and resonance relationships are therefore essential for the harmonious and viable behaviour of the single actors—as they ensure the resource availability through the satisfaction of the relationships between the viable systems and the referred supra-systems.

In order to coordinate the system equilibrium in its relational paths, the VSA state that sustainable plans for the acquisition of the resources necessary to satisfy the stakeholder network that hold them must be assigned to the decision-makers. In the most cases, a system negotiates internal ties (request of the sub-system) with external expectations (requests of the supra-system). To decision-makers, it is therefore requested attention in terms of: (1) capabilities of the elements in/of the system (intra-system relationships); (2) activities of other close and interested systems (inter-system relationships); and (3) influences of the supra-system (supra-system relationships). So they have the duty of structuring and coordinating tools, technics, and procedures in order to improve the system competitiveness and, by consequence, its survival possibilities. In several cases, the comprehension of the sustainable and viable relationships creation action represents, to some extent, a form of co-design, co-production, and co-creation (Barile \& Polese, 2009). In an attempt to enhance the VSA contribution in the understanding of the value co-creation process, we can refer to the evolution of the relationships between many-to-many type actors that, in the meanwhile, could turn out positive and harmonic, giving life to consonant and resonant interactions (Pels, Polese, \& Brodie, 2012). 
Within the application process of the intuitions deriving from the VSA to the company relationship management, the main character is, of course, the customer (Normann \& Ramirez, 1994; Ravald \& Groonroos, 1996; Groonroos, 1997). However, although the customers are the most important external entities for the value creation process, they are not the only ones. To this end, Gummesson (2008b) has introduced the "balanced centrality" concept in an attempt to reduce what he perceived as an overemphasis on the "customer's orientation".

In order to grant an adequate recognition of the other subjects and parts role in the value creation, Gummesson (2008b) enhance therefore the "many-to-many" approach, that extends the value creation notion to the interactions between the supplier networks and the consumer communities. According to this perspective, the value is generated through valuable proposals and the value actualization within: (1) the business-to-business relationships (B2B); (2) the customer-to-customer relationships (C2C); and (3) the interactions between companies and customers (B2C and C2B) (Gummesson, 2008a; Gummesson \& Polese, 2009). Moreover, because the supplier networks are not limited to the B2B relationships, but they extend to the relationships with a series of other interested subjects (or interested parts, actors), it has been suggested to widen these relationships (B2B, C2C, B2C/C2B) to the many-to-many approach integrating also the important relationships existing between the company and its stakeholders (B2S/S2B). A final improvement of the model shows that the consumer communities live in relation with the various interested parties (C2S/S2C), and that these relationships are able to influence the value creation process. The complete model is therefore represented by a sort of a "value pyramid" (Gummesson \& Polese, 2009), where it is represented a variety of relationships (B2B, B2C/C2B, C2C, B2S/S2B, C2S/S2C) which are managed within a system of value proposals (that are offered by the companies to possible markets, and so, expression of the potential value) and a system of value actualization (that are materialized by the market every time that the interaction occurs as result of choices and decision-making processes, therefore connected to the concrete and effective value) in order to co-create value (Gummesson \& Polese, 2009). The model indicates the reality in which supplier and customers are incorporated within complex relationships that comprehend exclusively its own network and communities, but also other interested subjects-which are able to influence, sometimes by force, the value creation within a service experience. Moreover, the model describes the dynamics existing between actors when one of them (usually a service supplier) offers service proposals that, in the end, are accepted and give rise to the effective co-creation of value, through the value realization due to the choice of a second actor (usually a customer). This recursive process interests, actually, a lot of actors because in is representation it is not dyadic at all.

As we stated before, the VSA represents an important source for the research on the service logic, and with reference to this please note that the theoretical proposal of the VSA is based on the relationships governance and management. As a matter of fact, the interesting suggestions coming from the VSA are connected to the capability that the system has to promote the relationships management through the evolution of satisfactory company dynamics. This seems to be absolutely in step with the value co-creation concept introduced by the S-D logic, which essentially refers to a process where all the actors must be satisfied in a widespread win-win interaction. However, the value co-creation occurs within dynamic interactions between several actors, and represents a status that is hard to realize by the decision-makers belonging to the entrepreneurial modern world. Although there is the recognition of the relationship importance-fundamental elements of value creation and 
sustainable behaviour - neither the S-D logic nor the SS, are mainly focused on the management of these relationships in order to achieve the benefit and the success of the single actor and on the way to do it dynamically, because of the more and more changeable conditions of the service exchange.

It is in this dynamic interaction that the $v S a$ contributes to the design and the governance of positive interactions between entities (Aguiari \& Di Nauta, 2012; Barile et al., 2012c). Companies, individuals, and decision-makers have to look into dynamic models based on supporting decision-making systems able to achieve satisfactory conditions with the involved decision-makers, seeking a continuous feedback directed to the productive processes, in order to adjust their features to the customers' needs (Saviano \& Di Nauta, 2011). It is co-design, co-production, and co-creation. This is what the VSA suggests to introduce a company behaviour in search of consonant and resonant interactions between the system actors. So, the VSA propose a useful model for the management of the relationships between actors, resources owners who need an integration for a successful service exchange. In this perspective, the VSA interprets the relationships between the actors as a continuous research of consonance and resonance. So, it is oriented toward the creation of virtuous network as constitutive elements of the service systems models. Thus, the VSA can be interpreted as a structure and methodology used to understand and to interpret the service system.

Which are the pillars of the co-creation in the S-D point of view? How a decision-maker can identify the actors with whom it has to interact, and how the resources interaction can effectively take place?

The VSA can contribute to answer to some of these questions, by introducing a methodology used to select and hierarchy ordinate all the possible resources owners which are the actors of the value co-creation process in the S-D logic. As a matter of fact, in the VSA, companies apply the competences and integrate them with other resources creating benefits (value co-creation), highlighting in this way the importance of these interactions for all the involved subjects.

Finallty, the most recent progresses done by the service research gradually have obscured the social-economic differences between the entities involved in the value creation process suggesting that all the relationships can be defined as A2A relationships (Vargo \& Lusch, 2011; Wieland, Polese, Vargo, \& Lusch, 2012). From this point of view, any entities can be considered as an actor, if it is involved in a dynamic process. Every organization can be an actor, each knot of a network can be it. The actors may be a system, a part of system, a supra-system, an interested part, an entity with a role, with a final goal, what else involved in a service provision activity, in a exchange moment, in a value co-creation process.

\section{Conclusions}

The service research has been often focused on the concept of the relationships between organizations and customers, highlighting its importance and arriving, in more recent times, to the formalization of A2A relationships.

We can see that it does not matter what is the qualification of the entities involved in studied processes. We note only the value of interactions between these entities. We do not continue to define the actor, rather we must deepen the effect of its actions. Any relationship we highlight has many entities (actors) operating within, especially in value co-creation understanding. In this perspective, a fundamental progress would be useful at this point of the research is the understanding and the interpretation of the relationships in order to deepen the issues 
concerning their governance and, by consequence, the governance of the organizations.

At the same time, the typical management disciplines seems to suffer the lack of a different perspective aimed at clarifying the dynamics which are at the base of the management action and that are oriented toward the governance of the organizations. The interpretative and methodological frame of the VSA represents to some extent the ideal cultural framework to allow the development of new conceptualizations that can group the interdisciplinary solicitations emerging form several research field, recovering the most significant and widen its horizon. The theme of complexity, the focus on emotional decision-making components, the spread of innovative concepts deriving from the natural science, provide for sure adequate stimulus and direct us toward the identification of new theoretical paths.

If this work highlight the "dream" of a new approach to the governance and the management, able to consider factors that since now have been often neglected or denied, then just the consonance conditions in the scholar context remains to be identified, in order that all this can take shape and become reality.

\section{References}

Achrol, R. S., \& Kotler, P. (2006). The service-dominant logic for marketing: A critique. In R. F. Lusch \& S. L. Vargo (Eds.), Toward a service-dominant logic of marketing: Dialog, debate, and directions (pp. 333-343). ME Sharpe, Armonk.

Aguiari, R. (2002). Introduzione al marketing. Bologna: Pitagora Editrice.

Aguiari, R., \& Di Nauta, P. (2012). Governing business dynamics in complex contexts. Mercati e Competitività, 1, 39-59.

Allee, V. (2000). Reconfiguring the value network. Journal of Business Strategy, 4, 36-41.

Alter, S. (2008). Service system fundamentals: Work system, value chain, and life cycle. In P. P. Maglio, \& J. Spohrer (Eds.), IBM Systems Journal, 47(1), 71-85.

Baccarani, C. (1997). Imprese commerciali e sistema distributivo: una visione economico-manageriale. Giappichelli.

Barile, S. (2000). Contributi sul pensiero sistemico in economia d'impresa. Roma: Arnia.

Barile, S. (2008). L'impresa come sistema. Contributi sull'approccio sistemico vitale (2nd ed.). Torino: Giappichelli.

Barile, S. (2009). Management Sistemico Vitale. Decidere in contesti complessi. Torino: Giappichelli.

Barile, S., \& Di Nauta, P. (2011). Viable systems approach for territory development. In S. Barile, C. Bassano, M. Calabrese, M. G. Confetto, P. Di Nauta, P. Piciocchi, F. Polese, M. Saviano, A. Siano, M. Siglioccolo, \& A. Vollero (Eds.), Contributions to theoretical and practical advances in management-A Viable Systems Approach (VSA) (pp. 199-243). Avellino: International Printing.

Barile, S., \& Polese, F. (2009). Service dominant logic and service science: A contribute deriving from network theories. In E. Gummesson, C. Mele, \& F. Polese (Eds.), The 2009 Naples Forum on Service: Service Science, S-D logic and Network Theory. Napoli: Giannini.

Barile, S., \& Polese, F. (2010a). Linking viable systems approach and many-to-many network approach to service-dominant logic and service science. International Journal of Quality and Service Sciences, 2(1), 23-42.

Barile, S., \& Polese, F. (2010b). Smart service systems and viable service systems. Service Science, 2(1), 21-40.

Barile, S., \& Polese, F. (2011). The viable systems approach and its potential contribution to marketing theory. In S. Barile, C. Bassano, M. Calabrese, M. G. Confetto, P. Di Nauta, P. Piciocchi, F. Polese, M. Saviano, A. Siano, M. Siglioccolo \& A. Vollero (Eds.), Contributions to Theoretical and Practical Advances in Management-A Viable Systems Approach (VSA) (pp. 139-173). Avellino: International Printing.

Barile, S., \& Saviano, M. (2008). Le basi del pensiero sistemico: la dicotomia struttura-sistema. In S. Barile (Ed.), L’impresa come sistema. Torino: Giappichelli.

Barile, S., \& Saviano, M. (2010). A new perspective of systems complexity in service science. Impresa, Ambiente, Management, 3(3), 375-414.

Barile, S., \& Saviano, M. (2011a). Foundations of systems thinking: The structure-system paradigm. In S. Barile, C. Bassano, M. Calabrese, M. G. Confetto, P. Di Nauta, P. Piciocchi, F. Polese, M. Saviano, A. Siano, M. Siglioccolo, \& A. Vollero (Eds.), (Eds.). Contributions to Theoretical and Practical Advances in Management-A Viable Systems Approach (VSA) (pp. 1-25). Avellino: International Printing. 
Barile, S., \& Saviano, M. (2011b). Qualifying the concept of systems complexity. In S. Barile, C. Bassano, M. Calabrese, M. G. Confetto, P. Di Nauta, P. Piciocchi, F. Polese, M. Saviano, A. Siano, M. Siglioccolo, \& A. Vollero (Eds.), Contributions to Theoretical and Practical Advances in Management-A Viable Systems Approach (VSA) (pp.27-63). Avellino: International Printing.

Barile, S., Montella, M., \& Saviano, M. (2011). Enhancement, value and viability of cultural heritage: Towards a service-based systems approach. In E. Gummesson, C. Mele, \& F. Polese (Eds.), Service-Dominant Logic, Network \& Systems Theory and Service Science (pp. 2-23). Napoli: Giannini.

Barile, S., Pels, J., Polese, F., \& Saviano, M. (2012a). An introduction to the viable systems approach and its contribution to marketing. Journal of Business Market Management, 5(2), 54-78.

Barile, S., Franco, G., Nota, G., \& Saviano, M. (2012b). Structure and dynamics of a "T-Shaped” knowledge: From individuals to cooperating communities of practice. Service Science, 4(2), 451-465.

Barile, S., Saviano, M., Polese, F., \& Di Nauta, P. (2012c). Reflections on service systems boundaries: A viable systems perspective: The case of the London Borough of Sutton. European Journal of Management, 30, 451-465.

Bartlett, C. A., \& Ghoshal, S. (1990). The multinational corporation as an interorganizational network. Academy of Management Review, 15(4), 603-625.

Basole, R. C., \& Rouse, W. B. (2008). Complexity of service value networks: Conceptualization and empirical investigation. In P. P. Maglio, \& J. Spohrer (Eds.), IBM Systems Journal, 47(1), 53-70.

Berry, L. L. (1980). Service marketing is different. Business, 30, 24-29.

Bitner, M. J. (1992). Servicescapes: The impact of physical surroundings on customers and employees. Journal of Marketing, 56, 57-71.

Borgonovi, E. (1996). Principi e sistemi aziendali per le amministrazioni pubbliche. Milano: Egea.

Capra, F. (1997). The web of life. London: Flamingo/HarperCollins.

Capra, F. (2002). The hidden connections. London: HarperCollins.

Carrubbo, L. (2009). Emerging value creation models: Contributes from service science, service dominant logic and viable systems approach. In E. Gummesson, C. Mele, \& F. Polese (Eds.), Service Science, S-D Logic and Network Theory. Napoli: Giannini.

Carrubbo, L. (2010). La service science: Stimoli e proposte per un destination management competitivo. Impresa Ambiente e Management, 4(2), 229-270.

Carrubbo, L., \& Ciasullo, M. V. (2011). Tourist systems co-creation exchanges: Service research and system thinking insights for destination competitiveness. In E. Gummesson, C. Mele, \& F. Polese (Eds.), System Theory and Service Science: Integrating Three Perspectives in a New Service Agenda. Napoli: Giannini.

Carrubbo, L., \& Sarno, S. (2010). Service innovation within new public governance theories e-platforms as smart service systems for public utilities. In Atti del 1st CooperLink Workshop, Ostersund (Sweden). Impresa Ambiente, Management, 4(3), $453-473$.

Castells, M. (1996). The rise of a network society. Oxford: Blackwell.

Cercola, R. (1996). La fine della dicotomia beni-servizi: nell'economia neo-industriale l'impresa deve creare valore per i partner. Sinergie, 40, 37-68.

Chesbrough, H. (2005). Towards a new science of services. Harvard Business Review (pp. 204-210).

Christopher, W. F. (2007). Holistic management-Managing what matters for company success. Hoboken: Wiley-Interscience.

De Santo, M., Pietrosanto, A., Napoletano, P., \& Carrubbo, L. (2011). Knowledge based service systems. In E. Gummesson, C. Mele, \& F. Polese (Eds.), System Theory and Service Science: Integrating Three Perspectives in a New Service Agenda. Napoli: Giannini.

Demirkan, H., \& Gauhl, M. (2006). Toward the service-oriented enterprise vision: Bridging industry and academics. Communications of the Association for Information Systems, 18, 546-556.

Di Nauta, P. (2010). A proposal for a parallelism between S-D logic and VSA. In International CooperLink Workshop the Emerging Perspective of Service Science for Management and Marketing Studies. Napoli: Giannini.

Drucker, P. F. (1993). Post capitalism society. Oxford: Butterworth Heinemann.

Forsgren, M., Holm, U., \& Johanson, J. (1991). Internalisation of the second degree. In Uppsala Working Paper, Uppsala University.

Golinelli, G. M. (2000). L'approccio sistemico al governo dell'impresa. L'impresa sistema vitale. Padova: Cedam.

Golinelli, G. M. (2005). L'approccio sistemico al governo dell'impresa. L'impresa sistema vitale. Padova: Cedam. 
Golinelli, G. M. (2008). L'approccio sistemico al governo dell'impresa. Verso la scientificazione dell'azione di governo. Padova: Cedam.

Golinelli, G. M. (2010). Viable systems approach (vsa), governing business dynamics. Padova: Kluwer Cedam.

Golinelli, G. M. (2011). L'approccio sistemico vitale (ASV) al governo dell'impresa. Verso la scientificazione dell'azione di governo. Padova: Cedam.

Granovetter, M. (1985). Economic action and social structure: The problem of embeddedness. American Journal of Sociology, 91, 481-510.

Grönroos, C. (1990). Service management: A management focus for service competition. International Journal of Service Industry Management, 1(1), 6-14.

Grönroos, C. (1996). Relationship marketing logic. The Asia-Australia Marketing Journal, 4(1), 7-18.

Grönroos, C. (1997). Value-driven relational marketing: From products to resources and competencies. Journal of Marketing Management, 13(5), 407-419.

Grönroos, C. (2006). What can a service logic offer to marketing theory? In R. F. Lusch, \& S. L. Vargo (Eds.), The Service-Dominant Logic of Marketing: Dialog, Debate, and Directions (pp. 320-333). ME Sharpe, Armonk.

Grönroos, C. (2008). Adopting a service business logic in relational business-to-business marketing: Value creation, interaction and joint value co-creation. Otago Forum, 2, 269-287.

Gulati, R. (1998). Alliances and networks. Strategic Management Journal, 19, 29-317.

Gummesson, E. (1987). The new marketing-Developing long-term interactive relationships—Long range planning. Elsevier.

Gummesson, E. (1993). Quality management in service organizations. St. John’s University and The International Service Quality Association (ISQA), New York.

Gummesson, E. (2004). Many-to-Many marketing. Malmö: Liber.

Gummesson, E. (2006). Marketing relazionale. Milano: Hoepli.

Gummesson, E. (2008a). Total relationship marketing. marketing management, relationship strategy, crm, and a new dominant logic for the value-creating network economy (III ed.). UK: Butterworth-Heinemann.

Gummesson, E. (2008b). Total relationship marketing (III ed.). Oxford: Butterworth-Heinemann/Elsevier.

Gummesson, E. (2009). Marketing as networks: The birth of many-to-many marketing. Stockholm: Publishing House Djursholm.

Gummesson, E., \& Polese, F. (2009). B2B is not an island! Journal of Business \& Industrial Marketing, 24(5), 337-350.

Håkansson, H., \& Östberg, G. (1975). Industrial marketing: An organizational problem? Industrial Marketing Management, 4(2/3), 113-123.

Håkansson, H., \& Snehota, I. (1995). Developing relationships in business network. London: Routledge.

Hedlund, G. (1986). The hypermodern MNC-A heterarchy? Human Resource Management, 25, 9-35.

Katzan, H. J. (2008). Foundations of service science concepts and facilities. Journal of Service Science, 1(1), 1-22.

Kotler, P. (1977). Marketing management: Analysis, planning, implementation, and control. Prentice Hall, Upper Saddle River.

Levitt, T. (1981). Marketing intangible products and products intangibles. Harvard Business Review, 59, 94-102.

Lovelock, C. (1983). Classifying services to gain strategic marketing insignhts. Journal of Marketing, 47(3), 9-20.

Lovelock, C., \& Gummesson, E. (2004). Whither services marketing? In search of a new paradigm and fresh perspectives. Journal of Service Research, 7, 20-41.

Lusch, R. F. (2011). Reframing supply-chain management: A service-dominant logic perspective. Journal of Supply Chain Management, 47(1), 14-18.

Lusch, R. F., Vargo, S. L., \& O’Brien, M. (2007). Competing through service: Insights from servicedominant logic. Journal of Retailing, 83, 5-18.

Maglio, P. P., \& Spohrer, J. (2008a). Fundamentals of service science. Journal of the Academy of Marketing Science, 36(1), 18-20.

Maglio, P. P., \& Spohrer, J. (2008b) (Eds.). Special issue on service science, management, and engineering. IBM Systems Journal, 47(1).

Maglio, P. P., Kieliszewski, C. A., \& Spohrer, J. C. (2010). Handbook of service science. New York: Springer.

Maglio, P. P., Srinivasan, S., Kreulen, J. T., \& Spohrer, J. (2006). Service systems, service scientists, SSME, and innovation. Communications of the ACM, 49, 81-85.

Mele, C. (2009). Value innovation in B2B: Learning, creativity, and the provision of solutions within service-dominant logic. Journal of Customer Behaviour, 8(3), 199-220.

Mele, C., \& Polese, F. (2011). Key dimensions of service systems: Interaction in social \& technological networks to foster value co-creation. In H. Demirkan, J. Spohrer, \& V. Krishna (Eds.), The Science of Service Systems (pp. 37-59). New York: Springer. 
Mele, C., Spena, T. R., \& Colurcio, M. (2010). Co-creating value innovation through resource integration. International Journal of Quality and Service Sciences, 2(1), 60-78.

Napoletano, P., \& Carrubbo, L. (2010). Becoming smarter: Towards a new generation of services systems. In Atti del 1st CooperLink Workshop, Ostersund (Sweden), Impresa Ambiente e Management 4(3), 415-438.

Normann, R. (1991). La gestione strategica dei servizi. Milano: Etas Libri.

Normann, R., \& Ramirez, R. (1994). Designing interactive strategy: From value chain to value constellation. Chichester: John Wiley \& Sons.

Parsons, T. (1965). Il Sistema sociale. Torino: Edizioni Comunità.

Pels, J., Brodie, R., \& Polese, F. (2012). Value co-creation: Using a viable systems approach to draw implications from organizational theories. Mercati \& Competitività, 1(12), 19-38.

Pine, B. J., \& Gilmore, J. H. (2000). L'economia della esperienze. Milano: Etas.

Polese, F. (2004). L'integrazione sistemica degli aggregati reticolari di impresa. Padova: CEDAM.

Polese, F. (2009a). Local government and networking trends supporting sustainable tourism: Some empirical evidences. In L. Fusco Girard \& P. Nijkamp (Eds.), Cultural Tourism and Sustainable Local Development (pp. 131-148). London: Ashgate.

Polese, F. (2009b). The influence of networking culture and social relationships on value creation. Sinergie, 16, $193-215$.

Polese, F., \& Carrubbo, L. (2008). Service dominant logic and its application on tourism phenomena. Impresa Ambiente e Management, II(1), 5-36.

Polese, F., \& Di Nauta, P. (2012, Forthcoming). A viable systems approach to relationship management in S-D logic and service science. Journal of Business Administration Review, 73(2), Schäffer-Poeschel.

Polese, F., \& Minguzzi, A. (2009). Networking approaches for sustainable destination management: an Italian case study. In M. Kozac, L. Andreu, \& J. Knoth (Eds.), Advances in Tourism Marketing, Managing Networks (pp. 113-124). London: Routledge.

Polese, F., Carrubbo, L., \& Russo, G. (2010). Managing business relationships: Between service culture and viable systems approach. Esperienze di Impresa, 2, 35-158.

Polese, F., Russo, G., \& Carrubbo, L. (2009). Service logic, value co-creation and networks: Three dimensions fostering inter-organisational relationships: Competitiveness in the boating industry. Proceedings of the 12th QMOD and Toulon-Verona Conference, Agosto.

Polese, F., Sarno, S., \& Carrubbo, L. (2009). Service science and innovation management: Sustainable service and quality performance in the value co-creating age. Atti del 12th Convegno TOULON Verona.

Polese, F., Moretta Tartaglione, A., Sarno, S., \& Carrubbo, L. (2009). An efficient value chain, or a service value network? Best practices deriving from Zara. In D. Vrontis, Y. Weber, R. Kaufmann, \& S. Tarba (Eds.), Managerial and Entrepreneurial Developments in the Mediterranean Area. Cipro: EuroMed Press.

Prahalad, C. K., \& Ramaswamy, V. (2000). Co-opting customer competence. Harvard Business Review, 78, 79-87.

Qiu, R. G., Fang, Z., Shen, H., \& Yu, M. (2007). Towards service science, engineering and practice. International Journal of Services Operations and Informatics, 2(2), 103-113.

Ravald, A., \& Grönroos, C. (1996). The value concept and relationship marketing. European Journal of Marketing, 30(2), 19-30.

Richardson, G. B. (1972). The organization of industry. The Economic Journal, 82(327), 883-896.

Rispoli, M., \& Tamma, M. (1992). Beni e servizi, cioè prodotti. Sinergie, 29, 95-115.

Rullani, E. (1997). Il ruolo dei servizi nella realtà dell'impresa moderna. Sinergie, 42, 45-59.

Rust, R. (2004). A call for a wider range of services research. Journal of Service Research, 6(3), 2-11.

Sampson, S. E., \& Froehle, C. M. (2006). Foundations and implications of a proposed unified services theory. Production and Operations Management, 15(2), 329-343.

Saviano, M. (1999). La strategia come scelta emergente dal dinamismo ambientale: Una rilettura del tema alla luce della visione sistemica. Esperienze d'impresa, 1, 107-128.

Saviano, M., \& Berardi, M. (2009). Decision making under complexity: The case of SME. In D. Vrontis, Y. Weber, R. Kaufmann, \& S. Tarba (Eds.), Managerial and Entrepreneurial Developments in the Mediterranean Area (pp. 1619-1643). Cipro: EuroMed Press.

Saviano, M., \& Di Nauta, P. (2011). Project management as a compass in complex decision making contexts: A viable systems approach. In D. Vrontis, Y. Weber, R. Kaufmann, \& S. Tarba (Eds.), 12th International Conference on Product Focused Software Development and Process Improvement (pp. 112-119). New York: ACM Association for Computing Machinery.

Sicca, L. M. (1996). Significati strategici del valore nell'economia neo-industriale. Economia e politica industriale, 23, $133-148$. 
Simon, H. A. (1969). The architecture of complexity. The sciences of the artificial. Cambridge: MIT Press.

Simon, H. A. (1945/1997). Administrative behavior: A study of decision-making processes in administrative organizations. New York: Free Press.

Spohrer, J., Anderson, L., Pass, N., \& Ager, T. (2008). Service science and service dominant logic. Otago Forum, 2, 4-18.

Spohrer, J., Maglio, P. P., Bailey, J., \& Gruhl, D. (2007). Steps toward a science of service systems. IEEE Computer, 40(1), 71-77.

Spohrer, J., Vargo, S. L., Maglio, P. P., \& Caswell, N. (2008). The service system is the basic abstraction of service science. HICSS Conference.

Vargo, S. L., \& Lusch, R. F. (2004). Evolving to a new dominant logic for marketing. Journal of Marketing, 68, 1-17.

Vargo, S. L., \& Lusch, R. F. (2006). Service-dominant logic: What it is, what it is not, what it might be. In R. F. Lusch, \& S. L. Vargo (Eds.). The Service-Dominant Logic of Marketing: Dialog, Debate, and Directions (pp. 43-56). Armonk: ME Sharpe.

Vargo, S. L., \& Lusch, R. F. (2008a). Service-dominant logic: Continuing the evolution. Journal of the Academy of Marketing Science, 36, 1-10.

Vargo, S. L., \& Lusch, R. F. (2008b). Why “service”? Journal of the Academy of Marketing Science, 36(1), 25-38.

Vargo, S. L., \& Lusch, R. F. (2011). It’s all B2B... and beyond: Toward a systems perspective of the market. Industrial Marketing Management, 40, 181-187.

Vargo, S. L., Lusch, R. F., \& Malter, A. J. (2006). Marketing as service-exchange: Taking a leadership role in global marketing management. Organizational Dynamics, 35(3), 264-277.

Vargo, S. L., Maglio, P. P., \& Akaka, M. A. (2008). On value and value co-creation: A service systems and service logic perspective. European Management Journal, 26(3), 145-152.

Vicari, S. (1991). L'impresa vivente. Milano: Etas.

Von Bertalanffy, L. (1956). General system theory. In F. E. Emery (Ed.), General System, Yearbook of the Society for the Advancement of General System Theory.

Wieland, H., Polese, F., Vargo, S., \& Lusch, R. (2012). Toward a service (eco)systems perspective on value creation. International Journal of Service Science, Management, Engineering and Technology, 3(3), 12-25.

Zeithaml, V. A., \& Bitner, M. J. (1996). Services marketing. New York: McGraw-Hill. 